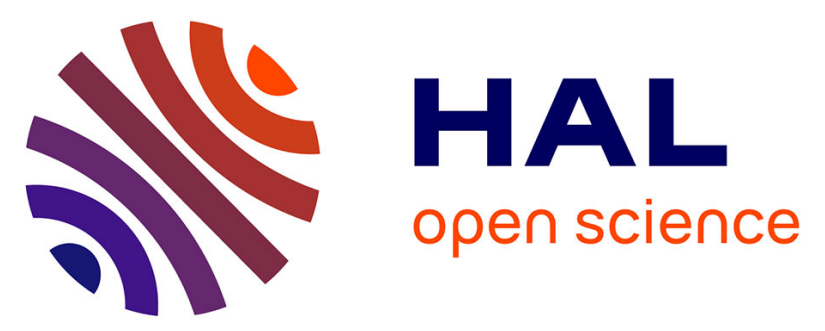

\title{
Contrasting effects of solar radiation and nitrates on the bioavailability of dissolved organic matter to marine bacteria
}

\author{
Marc Tedetti, Fabien Joux, Bruno Charrière, Kenneth Mopper, Richard
} Sempere

\section{To cite this version:}

Marc Tedetti, Fabien Joux, Bruno Charrière, Kenneth Mopper, Richard Sempere. Contrasting effects of solar radiation and nitrates on the bioavailability of dissolved organic matter to marine bacteria. Journal of Photochemistry and Photobiology A: Chemistry, 2009, 201 (2-3), pp.243-247. 10.1016/j.jphotochem.2008.11.002 . hal-02058596v2

\section{HAL Id: hal-02058596 \\ https: / hal-amu.archives-ouvertes.fr/hal-02058596v2}

Submitted on 29 Nov 2020

HAL is a multi-disciplinary open access archive for the deposit and dissemination of scientific research documents, whether they are published or not. The documents may come from teaching and research institutions in France or abroad, or from public or private research centers.
L'archive ouverte pluridisciplinaire HAL, est destinée au dépôt et à la diffusion de documents scientifiques de niveau recherche, publiés ou non, émanant des établissements d'enseignement et de recherche français ou étrangers, des laboratoires publics ou privés.

\section{(ㅇ)(1) $\$$}

Distributed under a Creative Commons Attribution - NonCommercial - NoDerivatives| 4.0 


\title{
Contrasting effects of solar radiation and nitrates on the bioavailability of dissolved organic matter to marine bacteria
}

\author{
Marc Tedetti ${ }^{\mathrm{a}, *}$, Fabien Joux ${ }^{\mathrm{b}, \mathrm{c}}$, Bruno Charrière ${ }^{\mathrm{a}}$, Kenneth Mopper ${ }^{\mathrm{d}}$, Richard Sempéré ${ }^{\mathrm{a}}$ \\ a Laboratoire de Microbiologie Géochimie et Ecologie Marines, CNRS/INSU, UMR 6117, Centre d'Océanologie de Marseille, \\ Université de la Méditerranée, Campus de Luminy, Case 901, F-13 288 Marseille Cedex 9, France \\ b UPMC Univ Paris 06, UMR 7621, LOBB, Observatoire Océanologique, F-66651, Banyuls/mer, France \\ c CNRS, UMR 7621, LOBB, Observatoire Océanologique, F-66651, Banyuls/mer, France \\ ${ }^{\mathrm{d}}$ Department of Chemistry and Biochemistry, Old Dominion University, Norfolk, VA, USA
}

\section{Introduction}

In the surface ocean, solar radiation induces the phototransformation of dissolved organic matter (DOM), which affects its bacterial utilization and fate [1,2]. The origin and chemical composition of DOM has been shown to influence its photoreactivity and its subsequent bioavailability [2]. In general, the irradiation of terrigenous or refractory deep-water DOM will have a net positive effect on its subsequent bacterial utilization through the formation of low molecular weight (LMW) bioavailable photoproducts, increasing bacterial production (BP) and respiration (BR) by 30-500\% [3]. By contrast, the irradiation of freshly produced plankton-derived DOM found in surface waters will have a net negative effect through the formation of biorefractory photoproducts, decreasing BP and BR by $10-100 \%[3]$.

This phototransformation of DOM proceeds via both direct and indirect reactions. The first involves absorption of photons by the molecular moiety that results in the observed reaction of interest. In most carbon related surface ocean processes, this direct absorption is by chromophoric DOM (CDOM) [4]. Indirect (or sensitized) processes refer to DOM reactions that proceed via free radicals [1] that are produced from a source other than the molecule undergoing the reaction of interest. Very often, this is CDOM that also serves as source of radicals (i.e. photosensitizer) for indirect photochemistry in the surface waters [5].

Nitrate $\left(\mathrm{NO}_{3}{ }^{-}\right)$could be equally considered a photosensitizer for DOM transformation. Indeed, $\mathrm{NO}_{3}{ }^{-}$efficiently absorbs ultravioletB radiation (UVBR: $280-315 \mathrm{~nm}$ ) to produce some free radicals [6] such as the hydroxyl radical $(\bullet \mathrm{OH})[7,8]$, which is one of the most reactive species in natural waters $[9,10]$. This photochemical role of $\mathrm{NO}_{3}{ }^{-}$may change with season with regard to modifications of solar irradiance spectrum, i.e. higher levels of UVBR in summer could lead to more direct absorption by $\mathrm{NO}_{3}{ }^{-}$. Recently, it has been shown that $\mathrm{NO}_{3}{ }^{-}$was involved in the photodegradation of dimethylsulfide (DMS) in oceanic waters [11], pesticides in surface waters [12] and in the photoproduction of dicarboxylic acids from unsaturated fatty acid in aqueous solution [13].

The main objective of this work is to assess the effects of solar radiation and $\mathrm{NO}_{3}{ }^{-}$on the bioavailability of DOM to bacterioplankton from coastal waters in the northwestern Mediterranean 
Sea. Irradiation and biodegradation experiments were conducted at two different seasons, i.e. early spring and early summer on $\mathrm{NO}_{3}{ }^{-}$-amended and unamended seawater samples. Here we investigate, through the measurement of BP and bacterial abundance (BA), the seasonal changes of DOM bioavailability, the role of $\mathrm{NO}_{3}{ }^{-}$ as a potential photosensitizer and the specific function of photosynthetically available radiation (PAR: $400-700 \mathrm{~nm}$ ), ultraviolet-A radiation (UVAR: $315-400 \mathrm{~nm}$ ) and UVBR in these processes.

\section{Materials and methods}

\subsection{Sample collection}

Seawater samples were collected in March and June 2003 at $3 \mathrm{~m}$ depth at the Station d'Observation Laboratoire Arago (SOLA), a shallow ( $\sim 26$ m depth) coastal station of the northwestern Mediterranean Sea located $\sim 500 \mathrm{~m}$ offshore of Banyuls-sur-mer, France $\left(42^{\circ} 29^{\prime} \mathrm{N}, 03^{\circ} 08^{\prime} \mathrm{E}\right.$; Fig. 1), using a 51 Niskin bottle deployed from the research vessel Néreis II. Seawater was transferred into an acidcleaned 201 polycarbonate carboy and immediately transported to the laboratory.

\subsection{Irradiation experiments}

Seawater was prefiltered through precombusted $\left(450^{\circ} \mathrm{C}, 6 \mathrm{~h}\right)$ GF/A glass fiber filters ( $90 \mathrm{~mm}$ filter diameter, Whatman) and then through $0.2 \mu \mathrm{m}$ polycarbonate filters $(90 \mathrm{~mm}$ filter diameter, Nuclepore), using a peristaltic pump with acid-cleaned silicon tubing. The $0.2 \mu \mathrm{m}$ filtered seawater (hereafter called DOM-solution) was distributed into precombusted 51 glass bottles and stored at $4{ }^{\circ} \mathrm{C}$ in the dark for $12 \mathrm{~h}$ before irradiation. A subsample of DOM-solution was then amended with $\mathrm{NO}_{3}{ }^{-}(30 \mu \mathrm{M}$ final concentration, Fluka). The $\mathrm{NO}_{3}{ }^{-}$-amended and unamended DOM-solutions were dispensed into precombusted quartz and borosilicate tubes ( $1 \mathrm{l}$ volume) sealed with acid-cleaned silicone stoppers wrapped in Teflon foil. The tubes were irradiated on 25 March and 27 June for $7 \mathrm{~h}$ (10:00 a.m. to $5: 00$ p.m.) under natural solar radiation in a recirculating water bath ( $0.1 \mathrm{~m}$ depth) maintained at in situ temperature (13.5 \pm 1 and $23 \pm 1{ }^{\circ} \mathrm{C}$ in March and June, respectively) that was set up on the pier near the Harbor of the institute. Four light conditions were simulated using different optical filters: (1) Dark (borosilicate tubes wrapped in aluminum foil), (2) PAR (borosilicate tubes wrapped in Lexan filter), (3) PAR + UVAR (quartz tubes wrapped in Mylar filter) and (4) Full Sun (FS = PAR + UVAR + UVBR; quartz tubes, no filter). Lexan and Mylar have 50\% transmittance at 380 and $320 \mathrm{~nm}$, respectively, and both filters have $~ 90 \%$ transmittance in PAR. Duplicate samples were irradiated for each light $/ \mathrm{NO}_{3}{ }^{-}$treatment. Incident irradiance was measured in the PAR, UVAR and UVBR domains using a broad band ELDONET radiometer (Real Time Computer, Inc.). In March and June, the PAR, UVAR and UVBR irradiances integrated over the exposure time (doses) were 7377,1067 and $18 \mathrm{~kJ} \mathrm{~m}^{-2}$, and 8322,1366 and $30 \mathrm{~kJ} \mathrm{~m}^{-2}$, respectively.

\subsection{Biodegradation experiments}

Seawater used for irradiation experiments was also filtered under a low vacuum $(<50 \mathrm{mmHg})$ through a $0.8 \mu \mathrm{m}$ polycarbonate filter ( $47 \mathrm{~mm}$ filter diameter, Nuclepore) to prepare the bacterial inoculum. During the irradiation of DOM-solutions, the bacterial inoculum was kept in the dark at in situ temperature. After exposure, DOM-solutions were inoculated with the (unirradiated) bacterial inoculum $(1 / 10$, inoculum/DOM-solution final ratio) to initiate biodegradation experiments. These mixed solutions were incubated in precombusted 11 glass bottles in the dark at $15 \pm 1$ and $20 \pm 1^{\circ} \mathrm{C}$ in March and June, respectively. No nutrients were added in the mixed solutions to measure the response of bacteria to "natural" conditions. BP and BA were measured before (T0) and after $48 \mathrm{~h}$ (T48) incubation. Duplicate samples were used for each light $/ \mathrm{NO}_{3}{ }^{-}$treatment.

\subsection{Analysis}

BP was measured by $\left[{ }^{3} \mathrm{H}\right]$ leucine incorporation into bacterial proteins [14] and BA by flow cytometry [15]. Chlorophyll $a$ (Chl a) was determined using a PerkinElmer MPF66 spectrofluorometer [16]. Dissolved organic carbon (DOC) was measured using a Shimadzu TOC-5000 carbon analyzer [17]. Fluorescent DOM was determined using a PerkinElmer LS55 spectrofluorometer (excitation wavelength: $350 \mathrm{~nm}$, emission wavelength: $450 \mathrm{~nm}$ ) standardized with a quinine sulfate solution $(1 \mathrm{QSU}=1 \mathrm{ppb}$ quinine sulfate in $\left.0.05 \mathrm{M} \mathrm{H}_{2} \mathrm{SO}_{4}\right)$ [18]. $\mathrm{NO}_{3}{ }^{-}$plus nitrite $\left(\mathrm{NO}_{2}{ }^{-}\right)$were analyzed with a Skalar autoanalyzer [19]. The method from [20] was used for reactive phosphorus $\left(\mathrm{PO}_{4}{ }^{3-}\right)$ analysis. All analyses were conducted in duplicate or triplicate.

\subsection{Statistics}

The effects of solar radiation and $\mathrm{NO}_{3}{ }^{-}$on $\mathrm{BP}, \mathrm{BA}$ and cell-specific activity $[(C S A=(B P / B A)]$ after $48 \mathrm{~h}$ incubation were assessed by oneway analyses of variance (ANOVA) performed with StatView 5.0 and the statistics package provided in Microsoft Excel 11.0. Samples were first considered as one group in a single classification ANOVA, ignoring the light $/ \mathrm{NO}_{3}{ }^{-}$treatments. When significant variance components were detected within the group, ANOVA were used to identify individual subgroups that were significantly different from each other [21]. Then, comparisons of BP, BA and CSA were

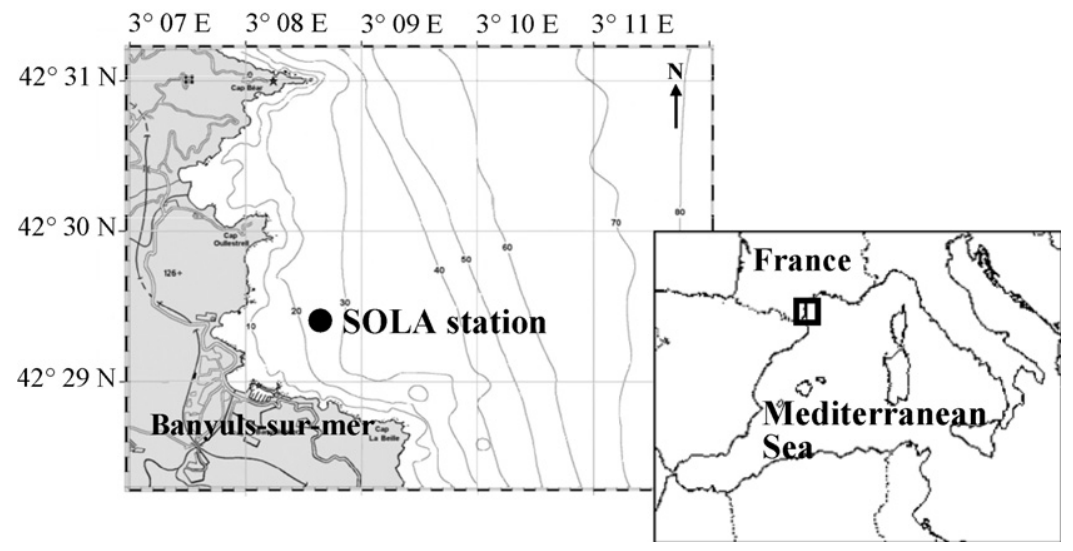

Fig. 1. SOLA sampling station located $\sim 500 \mathrm{~m}$ offshore of Banyuls-sur-Mer (France) in the northwestern Mediterranean Sea. 
Table 1

Composition of seawater samples collected at $3 \mathrm{~m}$ depth in the northwestern Mediterranean Sea (SOLA station, Bay of Banyuls) and used for the irradiation/biodegradation experiments.

\begin{tabular}{|c|c|c|c|c|c|c|c|c|}
\hline & Temp. $\left({ }^{\circ} \mathrm{C}\right)$ & Salinity (PSU) & Chl $a\left(\mu \mathrm{gl}^{-1}\right)$ & $\mathrm{DOC}(\mu \mathrm{M})$ & Fluorescence (QSU) & $\mathrm{NO}_{3}^{-}(\mu \mathrm{M})$ & $\mathrm{NO}_{2}^{-}(\mu \mathrm{M})$ & $\mathrm{PO}_{4}{ }^{3-}(\mu \mathrm{M})$ \\
\hline March & 13.5 & 35.8 & 0.53 & 78 & 1.5 & $\begin{array}{l}1.20 \\
33^{\mathrm{a}}\end{array}$ & $\begin{array}{l}0.11 \\
0.15^{a}\end{array}$ & $\begin{array}{l}0.03 \\
0.05^{a}\end{array}$ \\
\hline June & 23.0 & 37.2 & 0.29 & 84 & 1.3 & $\begin{array}{c}0.00 \\
29^{\mathrm{a}}\end{array}$ & $\begin{array}{l}0.00 \\
0.02^{\mathrm{a}}\end{array}$ & $\begin{array}{l}0.02 \\
0.04^{\mathrm{a}}\end{array}$ \\
\hline
\end{tabular}

Averaged values presented here are based on duplicate or triplicate analyses $(\mathrm{CV}<8 \%)$.

Temperature and salinity were obtained using a Sea-Bird Electronics (SBE) CTD.

a After addition of $30 \mu \mathrm{M} \mathrm{NO}_{3}{ }^{-}$in the DOM-solution.

made between the identified subgroups. The significance threshold was set at $p<0.05$ for $F(k-1, n-\mathrm{k})$, where $k$ is the number of groups/subgroups and $n$ is the total number of subjects.

\section{Results and discussion}

Table 1 presents the initial composition of seawater used for the irradiation/biodegradation experiments. Chl $a$ ranged from 0.29 (June) to $0.53 \mu \mathrm{gl}^{-1}$ (March). DOC was slightly lower in March $(78 \mu \mathrm{M})$ than in June $(84 \mu \mathrm{M})$, whereas fluorescent DOM presented the inverse pattern (1.5 and 1.3 QSU in March and June, respectively). $\mathrm{NO}_{3}{ }^{-}$and $\mathrm{NO}_{2}{ }^{-}$were higher in March $(1.2$ and $0.11 \mu \mathrm{M})$ than in June (limit of detection), whereas $\mathrm{PO}_{4}{ }^{3-}$ remained very low $(\sim 0.03 \mu \mathrm{M})$. After addition of $\mathrm{NO}_{3}{ }^{-}$, the latter reached 33 and $29 \mu \mathrm{M}$ in the DOM-solution in March and June, respectively.

Concerning the responses of bacteria to different DOMsolutions, in March, significant variance components were detected within the group of samples for BP, BA and CSA $(F(7,8)=4-21$, $p<0.05)$ (Fig. 2a, $c$ and e). Three subgroups significantly different from each other were identified: (1) Dark, Dark $+\mathrm{NO}_{3}{ }^{-}$, (2) PAR,

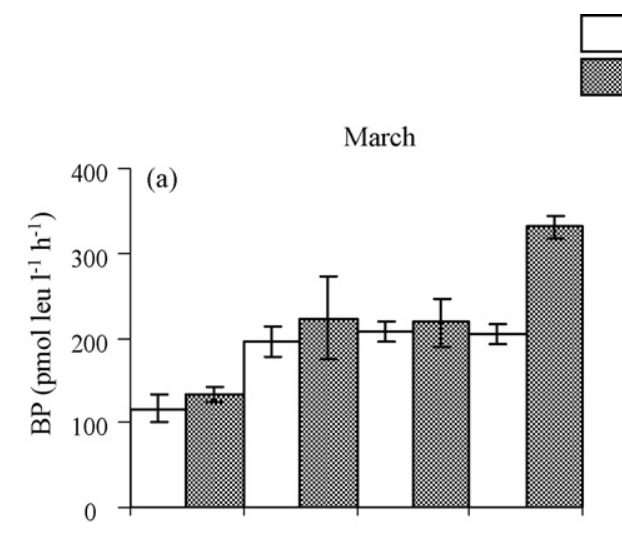

$-\mathrm{NO}_{3}^{-}$

$$
+\mathrm{NO}_{3}^{-}
$$
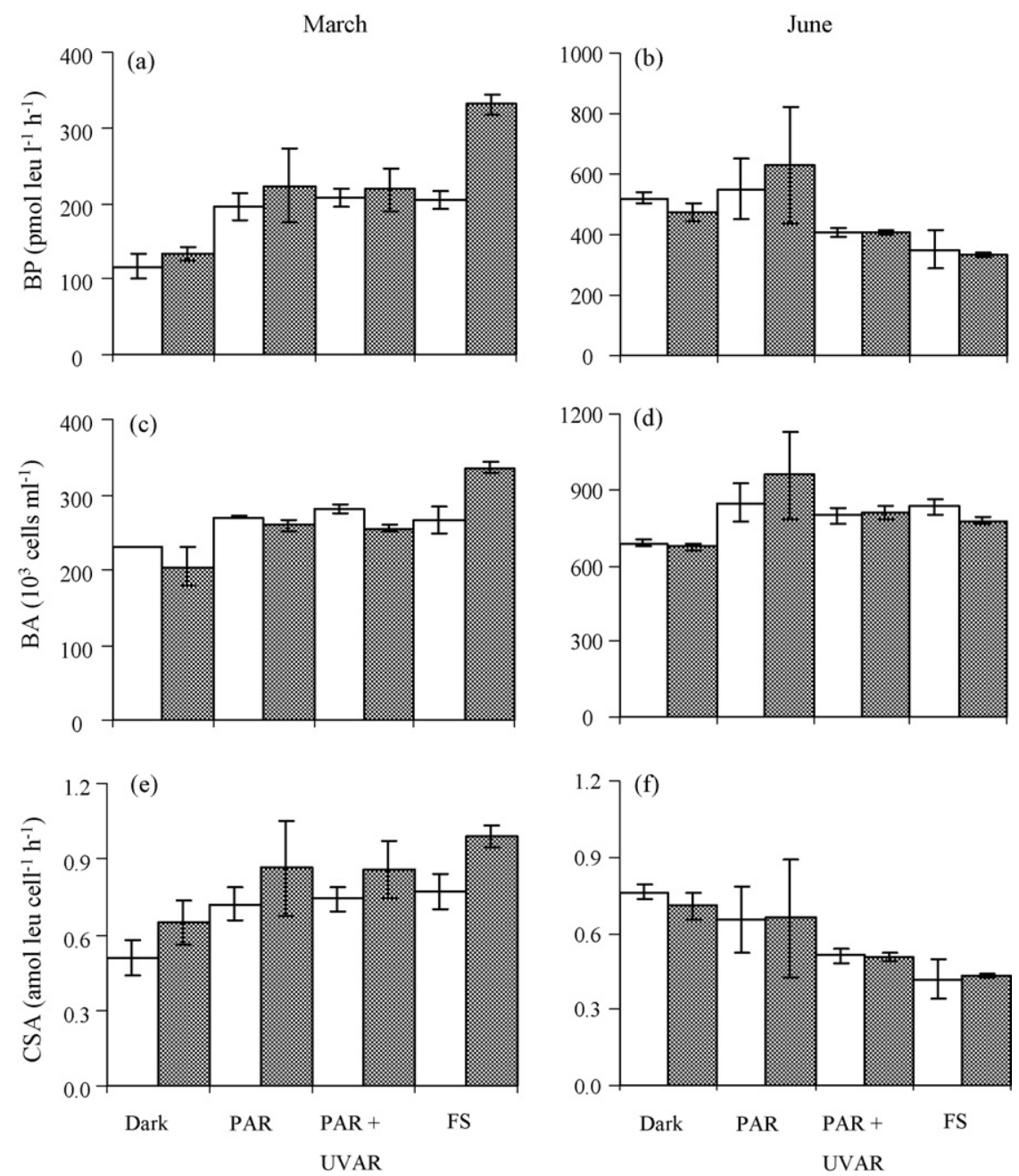

Fig. 2. Bacterial production ( $\mathrm{BP}$ in pmol leu $\mathrm{l}^{-1} \mathrm{~h}^{-1}$ ) $\left(\mathrm{a}\right.$ and $\mathrm{b}$ ), bacterial abundance (BA in $10^{3}$ cells ml ${ }^{-1}$ ) (c and $\left.\mathrm{d}\right)$ and cell-specific activity (CSA $=\mathrm{BP} / \mathrm{BA}$ in amol leu cell ${ }^{-1}$ $\mathrm{h}^{-1}, \mathrm{amol}=10^{-18} \mathrm{~mol}$ ) (e and f) measured after $48 \mathrm{~h}$ incubation with dissolved organic matter exposed to PAR, PAR + UVAR, Full Sun (FS = PAR + UVAR + UVBR) or kept in the dark, for experiments conducted in March and June 2003. Standard deviations are based on duplicate samples. 
$\mathrm{PAR}+\mathrm{NO}_{3}{ }^{-}, \mathrm{PAR}+\mathrm{UVAR}, \mathrm{PAR}+\mathrm{UVAR}+\mathrm{NO}_{3}{ }^{-}, \mathrm{FS}$ and (3) $\mathrm{FS}+\mathrm{NO}_{3}{ }^{-}$ $(F(1,10)=7-49, p<0.05 ; F(1,12)=11-45, p<0.01)$. For the $\mathrm{NO}_{3}{ }^{-}-$ unamended samples, BP increased on average by $80 \%$, BA by $20 \%$ and CSA by $40 \%$ in PAR, PAR + UVAR or FS (subgroup 2) compared to Dark (subgroup 1) (Fig. 2a, c and e). Clearly, in March, the irradiation of $\mathrm{NO}_{3}{ }^{-}$-unamended DOM-solution led to an increase in BP, BA and CSA in the mixed solution after $48 \mathrm{~h}$ incubation compared to the unirradiated solution. This increase was due essentially to PAR with no significant effect of UVAR and UVBR (Fig. 2a, $c$ and e). It could be explained by a photoproduction of LMW bioavailable compounds from the direct absorption of PAR by CDOM [1,22]. With the addition of UVAR and UVBR, some additional LMW substrates may be also produced from CDOM but without any significant enhancement of BP [23].

When $\mathrm{NO}_{3}{ }^{-}$was added to the DOM-solution, BP increased on average by 80 and $150 \%$, BA by 20 and $65 \%$, and CSA by 40 and $50 \%$ in PAR or PAR + UVAR (subgroup 2) and FS (subgroup 3) compared to Dark (subgroup 1), respectively (Fig. 2a, c and e). These results confirm the role of PAR in the increase of BP, BA and CSA, but in this case, UVBR also played a significant role, whereas UVAR had no effect. Consequently, in March, the addition of $\mathrm{NO}_{3}{ }^{-}$during irradiation of the DOM-solution led to a positive effect of UVBR on bacterial growth (Fig. 2a, c and e). This positive effect likely occurs through the action of $\bullet \mathrm{OH}$ that are released from the UVB photolysis of $\mathrm{NO}_{3}{ }^{-}$[7]. When produced in seawater, ${ }^{\bullet} \mathrm{OH}$ reacts almost exclusively with bromide ion to produce bromide radical $\left(\mathrm{Br}_{2}{ }^{--}\right)$, and to a lesser extent with the carbonate system and DOM [11,24]. As demonstrated for the degradation of DMS [11], $\mathrm{Br}_{2}{ }^{-}$could be one of the radical species involved in the degradation of DOM, leading to the production of other LMW bioavailable substrates that in turn could substantially enhance bacterial growth. Therefore, in March, two different photochemical pathways were observed for the stimulation of BP, BA and CSA: (1) the direct absorption of PAR by CDOM and (2) the reaction between DOM and $\bullet \mathrm{OH}$-derived radicals that were produced from the direct absorption of UVBR by $\mathrm{NO}_{3}{ }^{-}$.

In June, significant variance components were detected within the group of samples for BP, BA and CSA $(F(7,8)=4-11, p<0.05)$ (Fig. 2b, d and f). Two different subgroups were identified: (1) Dark, Dark $+\mathrm{NO}_{3}{ }^{-}, \mathrm{PAR}, \mathrm{PAR}+\mathrm{NO}_{3}{ }^{-}$and (2) PAR + UVAR, $\mathrm{PAR}+\mathrm{UVAR}+\mathrm{NO}_{3}{ }^{-}, \mathrm{FS}, \mathrm{FS}+\mathrm{NO}_{3}{ }^{-}(F(1,14)=19-52, p<0.001)$ for $\mathrm{BP}$ and CSA, and (1) Dark, Dark $+\mathrm{NO}_{3}{ }^{-}$and (2) all other light conditions $(F(1,14)=13, p<0.005)$ for BA. For the $\mathrm{NO}_{3}{ }^{-}$-amended and unamended DOM-solutions, BP decreased on average by $30 \%$ and CSA by $35 \%$ in PAR + UVAR or FS (subgroup 2) compared to Dark or PAR (subgroup 1) (Fig. 2b and f). On the other hand, BA increased on average by $23 \%$ in PAR, PAR + UVAR or FS (subgroup 2) compared to Dark (subgroup 1) (Fig. 2d). Consequently, in June, the irradiation of $\mathrm{NO}_{3}{ }^{-}$-amended and unamended DOM-solution led to a decrease in BP and CSA, and to an increase in BA in the mixed solution after $48 \mathrm{~h}$ incubation compared to the unirradiated solution. Clearly, UVAR was responsible for the inhibition of BP and CSA, whereas $\mathrm{NO}_{3}{ }^{-}$, PAR and UVBR had no significant effect. By contrast, the stimulation of BA was due essentially to PAR, whereas $\mathrm{NO}_{3}{ }^{-}$, UVAR and UVBR had no significant effect (Fig. 2b, $\mathrm{d}$ and f). The negative effect of UVAR on BP may be explained by a photomineralization (loss) of biomolecules [25] or their phototransformation into biorefractory compounds ("humification" processes) [26] from the direct absorption of UVAR by CDOM. Although the addition of UVBR may stimulate these photochemical processes (mineralization and humification), it did not lead to supplementary BP inhibition, probably because the UVBR flux was tiny compared with PAR and UVAR. Therefore, in June, the subsequent decrease of BP was only due to the direct absorption of UVAR by CDOM. Note that for both the experiments, the addition of $\mathrm{NO}_{3}{ }^{-}$in the dark treatments had no effect on $\mathrm{BP}$ (Dark and Dark $+\mathrm{NO}_{3}{ }^{-}$in the same subgroup) meaning that $\mathrm{NO}_{3}{ }^{-}$alone did not cause a shift in the amount of carbon used for BP.

The difference of bacterial responses between March (stimulation of BP and BA) and June (inhibition of BP and stimulation of BA) probably reflects differences in the DOM quality between these two periods [2]. In June, the fraction of fluorescent DOM is lower than in March (0.015 and $0.019 \mathrm{QSU} \mu \mathrm{M} \mathrm{DOC}^{-1}$, respectively). Indeed, due to seasonal effects, DOM samples in June were likely more photoprocessed than those of March. The degradation/bleaching of the sunlight-absorbing compounds could have an impact on DOM composition. Whereas in March DOM undergoes photoprocessing that increases its bioavailability and leads to the consumption of the relevant molecules, in June the same molecules could be no longer present (or be present in much lower amount) due to the previous, combined photochemical and microbiological processing. Moreover, the role of $\mathrm{NO}_{3}{ }^{-}$as a potential photosensitizer, observed in March but not in June (despite the higher UVBR doses at this season), seems to depend on this DOM quality. It is also possible that the variations of temperature between March $\left(13.5^{\circ} \mathrm{C}\right)$ and June $\left(23.0^{\circ} \mathrm{C}\right)$ had an influence on these bacterial responses. This study highlights contrasting effects of solar radiation and $\mathrm{NO}_{3}{ }^{-}$on the bioavailability of DOM to bacterioplankton for coastal waters in the northwestern Mediterranean Sea. Our major findings are: (1) in spring, a significant role of PAR in the subsequent stimulation of $\mathrm{BP},(2)$ a potential role of $\mathrm{NO}_{3}{ }^{-}$as a photosensitizer (through the action of UVBR) in this BP stimulation and (3) in summer, a significant role of UVAR in the subsequent inhibition of BP without any significant role of $\mathrm{NO}_{3}{ }^{-}$.

The $\mathrm{NO}_{3}{ }^{-}$and humic-rich DOC inputs from the Rhône River, the largest river of the northwestern Mediterranean Sea, may represent about $96 \mathrm{kt} \mathrm{NO}_{3}{ }^{-}$year $^{-1}$ and $130 \mathrm{kt} \mathrm{Cyear}^{-1}[27,28]$. Consequently, the combination of high levels of UVBR with large $\mathrm{NO}_{3}{ }^{-}$inputs from estuaries and river plumes or from nutrient-rich deep waters (upwelling) could strongly stimulate photochemical processes such as the production of $\bullet \mathrm{OH}$ and then participate to the photosensitized transformation of DOM and its subsequent bacterial utilization, as we observed in spring with the addition of $30 \mu \mathrm{M} \mathrm{NO}_{3}{ }^{-}$. For instance, we measured, by using the method described in [7] (i.e. benzoic acid probe introduced in large excess prior to the irradiation of samples), a photoproduction of $100-150 \mathrm{nM} \cdot \mathrm{OH} \mathrm{h}^{-1}$ for water from the Rhône River compared to $2-4 \mathrm{nM}^{\bullet} \mathrm{OHh}^{-1}$ for marine water from the northwestern Mediterranean Sea exposed to similar solar radiation [Tedetti and Sempéré, unpublished data]. However, - OH production may also result from the photolysis of CDOM. Further studies will be necessary to determine more accurately the respective role of $\mathrm{NO}_{3}{ }^{-}$and $\mathrm{CDOM}$ as photosensitizers, as well as to better discriminate the role of PAR, UVAR and UVBR in DOM phototransformation.

\section{Acknowledgments}

We thank L. Oriol and M. Pujo-Pay for nutrients and DOC analysis, P. Catala for flow cytometry analysis and the Service d'Observation du Laboratoire Arago for providing CTD data. We also thank W.L. Miller, F. Van Wambeke, J.R. Helms and A. Stubbins for their helpful suggestions and discussions. We are grateful to two anonymous referees for improving the quality of this manuscript. This research was funded by the Programme National Environment Côtier (PNEC) and CNRS-PROOF project UVECO. Funding from the region of Provence Alpes Côte d'Azur, the College Doctoral FrancoJaponais and AtmoPACA to M.T. is gratefully acknowledged.

\section{References}

[1] K. Mopper, D.J. Kieber, Marine photochemistry and its impact on carbon cycling, in: S. de Mora, S. Demers, M. Vernet (Eds.), The Effects of UV Radiation in 

the Marine Environment, Cambridge University Press, Cambridge, 2000, pp.
101-129.

[2] M.A. Moran, J.S. Covert, Photochemically mediated linkages between dissolved organic matter and bacterioplankton, in: S.E.G. Findlay, R.L. Sinsabaugh (Eds.), Aquatic Ecosystems: Interactivity of Dissolved Organic Matter, Academic Press, San Diego, 2003, pp. 243-262.

[3] K. Mopper, D.J. Kieber, Photochemistry and the cycling of carbon, sulphur, nitrogen and phosphorus, in: D.A. Hansell, C.A. Carlson (Eds.), Biogeochemistry of Marine Dissolved Organic Matter, Academic Press, San Diego, 2002, pp. 455-507.

[4] R.G. Zepp, Environmental photoprocesses involving natural organic matter, in: F.H. Frimmel, R.F. Christman (Eds.), Humic Substances and Their Role in the Environment, John Wiley \& Sons, New York, 1988, pp. 193-214.

[5] R.G. Zepp, P.F. Schlotzhauer, R.M. Sink, Environ. Sci. Technol. 19 (2003) 74-81.

[6] J. Mack, J.R. Bolton, J. Photochem. Photobiol. A: Chem. 128 (1999) 1-13.

[7] J. Qian, K. Mopper, D.J. Kieber, Deep-Sea Res. I 48 (2001) 741-759.

[8] K. Takeda, H. Takedoi, S. Yamaji, K. Ohta, H. Sakugawa, Anal. Sci. 20 (2004) 153-158.

[9] T. Mill, Chemical and photooxidation, in: O. Hutzinger (Ed.), The Handbook of Environmental Chemistry, vol. 2, Part A, Springer, Berlin, 1980, pp. 77-105.

[10] O.C. Zafiriou, J. Joussot-Dubien, R.G. Zepp, R.G. Zika, Environ. Sci. Technol. 18 (1984) 356-371.

[11] R.-C. Bouillon, W.L. Miller, Environ. Sci. Technol. 39 (2005) 9471-9477.

[12] C. Richard, Halle Ater, O. Brahmia, M. Malouki, S. Halladja, Catal. Today 124 (2007) 82-87.

[13] M. Tedetti, K. Kawamura, M. Narukawa, F. Joux, B. Charrière, R. Sempéré, J. Photochem. Photobiol. A: Chem. 188 (2007) 135-139.
[14] D.L. Kirchman, Leucine incorporation as a measure of biomass production by heterotrophic bacteria, in: P.F. Kemp (Ed.), Handbook of Methods in Aquatic Microbial Ecology, Lewis Publishers, Boca Raton, 1993, pp. 509-512.

[15] F. Joux, H. Agogué, I. Obernosterer, C. Dupuy, T. Reinthaler, G.J. Herndl, P. Lebaron, Aquat. Microb. Ecol. 42 (2006) 91-104.

[16] J. Neveux, F. Lantoine, Deep-Sea Res. 40 (1993) 1747-1764.

[17] R. Sohrin, R. Sempéré, J. Geophys. Res. vol. 110, C10S90 (2005), doi:10.1029/ 2004JC002731.

[18] I. Obernosterer, B. Reitner, G.J. Herndl, Limnol. Oceanogr. 44 (1999) 1645-1654.

[19] P. Tréguer, P. Le Corre, Manuel d'analyses des sels nutritifs dans l'eau de mer, Laboratoire d'Océanographie Chimique, Université de Bretagne Occidentale, Brest (1975), p. 110.

[20] J. Murphy, J.P. Riley, Anal. Chim. Acta 27 (1962) 31-36.

[21] R.R. Sokal, J.F. Rohlf, Nested analysis of variance, in: R.R. Sokal, J.F. Rohlf (Eds.) Biometry: The Principles and Practice of Statistics in Biological Research, 2nd ed., WH Freeman and Company, San Francisco, 1981, pp. 271-320.

[22] I. Reche, M.L. Pace, J.J. Cole, Ecosystems 3 (2000) 419-432.

[23] R.M.W. Amon, R. Benner, Geochim. Cosmochim. Acta 60 (1996) 1783-1792.

[24] M.J. Pullin, S. Bertilsson, J.V. Goldstone, B.M. Voelker, Limnol. Oceanogr. 49 (2004) 2011-2022.

[25] L.J. Tranvik, S. Bertilsson, Ecol. Lett. 4 (2001) 458-463.

[26] R.J. Kieber, L.H. Hydro, P.J. Seaton, Limnol. Oceanogr. 42 (1997) 1454-1462.

[27] T. Moutin, P. Raimbault, H.L. Golterman, B. Coste, Hydrobiologia 373 (1998) 237-248.

[28] R. Sempéré, B. Charriere, G. Cauwet, F. Van-wambeke, Global Biogeochem. Cycles 14 (2000) 669-681. 